\title{
N-ethoxyethylpiperidine, Trimecaine and Piromecaine Based Ionic Compounds: Synthesis and Prediction of Biological Activity
}

\author{
D. S. Zolotareva, A. A. Basharimova, S. Bayazit, V. K. Yu, and A. G. Zazybin
}

\begin{abstract}
Herein we report on the synthesis of new ionic compounds based on N-ethoxyethylpiperidine, trimecaine and piromecaine, obtained via $\mathrm{N}$-alkylation with alkyl halides. The combination of piperidine ring, secondary amine group, trimecaine and piromecaine in form of a base with different alkyl radicals bring to molecule new biological activity and/or reduce toxic effects of parent compounds. The potential pharmacological activity and potential toxic effects of the obtained compounds were predicted with PASS online service (Prediction of Activity Spectra for Substances) showing cardiotonic, antiarrhythmic and spasmolytic potential activities. The dependence of the potential activity on the nature of substituent was compared. These novel ionic compounds can be applied for synthesis of ionic compounds and drug candidates.
\end{abstract}

Index Terms-Ionic liquids, N-ethoxyethylpiperidine, PASS prediction, piromecaine, trimecaine.

\section{INTRODUCTION}

One of the main strategies of the search for new biologically active compounds in the last decade is a combination of two or more pharmacophore groups in one compound [1]. In this manusctipt we are now taking this strategy to a relatively new class of organic compounds - ionic liquids. One well-known example of a successful transition from the molecular (non-ionic) form of the drug to the ionic liquid form is lidocaine docusate [2] - an ionic form of lidocaine is better absorbed by the organism and has a combination of analgesic and emollient properties. The presence of piperidine ring and/or secondary amide group appears to be very interesting in terms of the search for new biologically active compounds [3]-[5]. Especially it worth mentioning the piperidine derivatives those include the general structural part $\mathrm{N}$-ethoxyethylpiperidine, where the ethoxyethyl substituent plays an important role in the occurrence of biological activity [6]. N-ethoxyethylpiperidine derivative:

1-(2-ethoxyethyl)-4-ethynyl-4-benzoyloxy-piperidine hydroc hloride known as kazcaine shows anesthetic and

Manuscript received January 20, 2017; revised May 6, 2017. This work supported by Ministry of Education and Science of Republic of Kazakhstan under Grants 1318/GF4, 1752/GF4, 0650/GF4 and 0251/PTF.

D. S. Zolotareva, A. A. Basharimova, S. Bayazit, A. G. Zazybin are with the Center of Chemical Engineering, Kazakh-British Technical University, 59 Tole-bi street, Almaty, 050000, Kazakhstan (e-mail: zolotareva.2909@mail.ru, bayazitsarah@gmail.com, azazybin@yahoo.com).

V. K. Yu is with Institute of Chemical Sciences named after A.B. Bekturov, Walikhanov Str., 106, Almaty 050010, Kazakhstan (e-mail: yu_vk@mail.ru). anti-arrhythmic activity with no teratogenic, embriotoxic, mutagenic and allergic effects [7]. Trimecaine which we used in our research as a parent compound nowadays has been applied as a local anesthetic and antiarrhythmic and in cardio surgery [8], [9]. Piromecaine also shows local anesthetic and antiarrhythmic activity [10], [11]. To define the range of biological activity of new synthesized compounds we used Pass online service (Prediction of Activity Spectra for Substances) [12], which helps to predict biological and pharmacological effects, action mechanisms and also toxicity and adverse impact of compound, for example as in [13] [15]. In this manuscript we report some methods for the synthesis of new ionic compounds and study of their potential biological activity.

\section{SYNTHESIS OF THE IONIC COMPOUNDS BASED ON} $\mathrm{N}$-ETHOXYETHYLPIPERIDINE

The acetylene alcohol compound 1-(2-ethoxyethyl)-4-ethynylpiperidin-4-ol was chosen as a starting compound for the synthesis of new ionic substances drug candidates. 1-(2-ethoxyethyl)-4-ethynylpiperidin-4-ol was synthesized as hydrochloride by the Favorskii reaction from 1-(2-ethoxyethyl)-4-piperidone according to the well-known procedure [16]. For the purpose of new ionic compounds synthesis it was transferred into the form of a base and then undergone the process of alkylation with alkyl halides.

The general procedure for the alkylation is a treating of 1-(2-ethoxyethyl)-4-ethynylpiperidin-4-ol with acetonitrile solution of corresponding alkyl halide. The mixture is taken under reflux for $0.5-12$ hours. Then the obtained compound is purified with different methods.

At first the ionic compound based on 1-(2-ethoxyethyl)-4-acetyl-4-hydroxypiperidine and methyl iodide 1-(2-ethoxyethyl) -4-ethynyl-4-hydroxy-1-methylpiperidine iodide was synthesized (1) (Fig. 1). Synthesis was carried out in acetonitrile medium under the reflux for 1 hour.

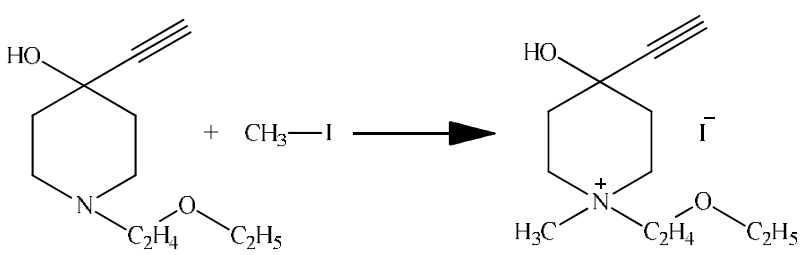

(1)

Fig. 1. Synthesis of

1-(2-ethoxyethyl)-4-ethynyl-4-hydroxy-1-methylpiperidinium iodide (1). 
Purification of the product was carried out by crystallization from acetone. In the IR spectrum of the product the shift of vibration bands $\left(\mathrm{cm}^{-1}\right)$ of the functional groups in comparison to the starting material was observed: $3266(\mathrm{O}-\mathrm{H})$; $2109(\mathrm{C} \equiv \mathrm{C}), 1276,1192,1173(\mathrm{C}-\mathrm{O}), 859(\mathrm{C}-\mathrm{N})$ for the product (1) and $3238(\mathrm{O}-\mathrm{H}) ; 2097(\mathrm{C} \equiv \mathrm{C}), 1288,1257,1226$ $(\mathrm{C}-\mathrm{O}), \quad 880 \quad(\mathrm{C}-\mathrm{N})$ for the initial 1-(2-ethoxyethyl)-4-ethynylpiperidin-4-ol.

The mass spectrum of the alkylation product was recorded and the signal with mass 212.2 , corresponding the cationic part of 1- (2-ethoxyethyl) -4-ethynyl-4-hydroxy-1-methyl-piperidinium iodide (1) was detected.

For the synthesis of ionic compound with ethyl moiety at the nitrogen atom 1-(2-ethoxyethyl)-4-ethynylpiperidin-4-ol was reacted with ethyl iodide (Fig. 2). The reaction was performed for 3.5 hours under the reflux in acetonitrile medium to get product (2).

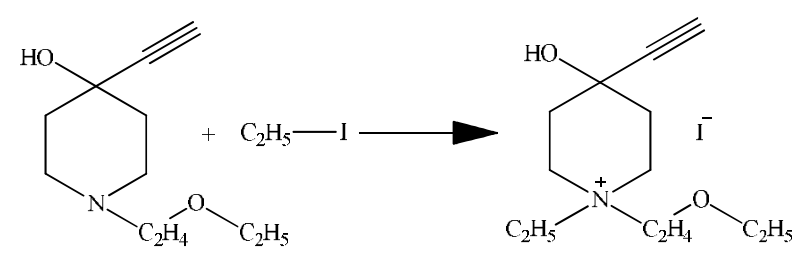

(2)

Fig. 2. Synthesis of 1- (2-ethoxyethyl) -4-ethynyl-4-hydroxy-1-ethylpiperidinium iodide (2).

After removal of the solvent the yellow liquid was obtained, that doesn't harden at a temperature $-19^{\circ} \mathrm{C}$, indicating the formation of the ionic liquid. The IR spectrum of the alkylation product shows vibration bands $\left(\mathrm{cm}^{-1}\right)$ of the functional groups different from the starting material: 3239

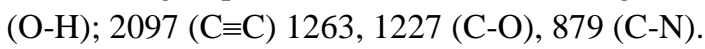

In the mass spectrum of the alkylation product the signal with mass 226.2 was detected, corresponding to the cationic part of 1-(2-ethoxyethyl) -4-ethynyl-4-hydroxy-1-ethyl-piperidinium iodide (2).

In the proton spectrum of the sample the peaks of the methyl groups are observed at 1.17 and $1.40 \mathrm{ppm}$. The peaks at 2.23-2.52 and 3.77-3.91 ppm belong to the equivalent protons of heterocycle. Singlet with chemical shift at 2.75 ppm can be attributed to the proton at sp-hybridized carbon atom. Methylene protons resonate at 3.49-3.86 ppm.

In the carbon spectrum most highfield peaks at 8.65 and $15.20 \mathrm{ppm}$ can be attributed to the methyl carbons. Symmetrically arranged atoms of the piperidine ring resonate at 33.21 and $67.33 \mathrm{ppm}$. Methylene atoms give signals with the chemical shifts of $56.20,62.76$ and $63.82 \mathrm{ppm}$. The resonance lines at 74.41 and $84.85 \mathrm{ppm}$ correspond to sp-hybridized carbon atoms.

\section{SyNTHESIS OF IONIC COMPOUNDS BASED ON TRIMECAINE AND PIROMECAINE}

Trimecaine and piromecaine are widely used drugs having local anesthetic and antiarrhythmic activity [17] find application in ophthalmology and otolaryngology, for anesthesia in endoscopic studies; intravenously appointed at gastric arrhythmia, at cardiac glycoside intoxication, at acute myocardial infarct [18]. At the same time, ionic compounds based on them are not well studied, especially in terms of their pharmacological activity. In this section, we report on the synthesis of ionic compounds based on trimecaine and piromecaine and study of their physical and chemical characteristics.

In both cases, the pharmaceutical substance was taken in the hydrochloride form. Trimecaine represents the hydrochloride of 2,4,6-trimetilanilide of $\mathrm{N}, \mathrm{N}$-diethylamine-acetic acid and piromecaine represents the hydrochloride of 2,4,6trimethylanilide-1-butyl-pyrrolidine-2-carboxylic acid. Structures are shown in Fig. 3.

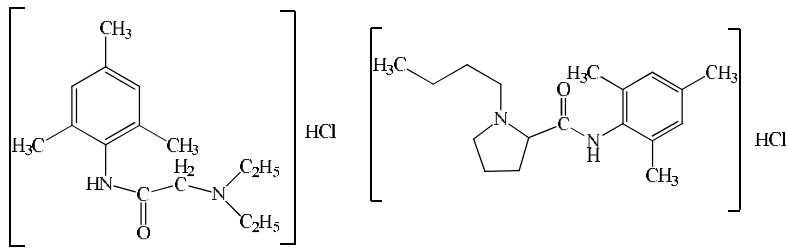

Fig. 3. Structure of hydrochloride form of trimecaine (left) and piromecaine (right).

To carry out the alkylation reaction trimecaine hydrochloride was transferred into the form of a base by reaction with potassium carbonate, the product was isolated from the aqueous solution by extraction with benzene. Firstly we synthesized (Fig. 4) N, $\mathrm{N}$-diethyl-2-(mesitylamino)-N-methyl-oxoethanaminium iodide (3) by alkylation of trimecaine with methyl iodide. After mixing of acetonitrile solutions of reagents the reaction mixture was left at room temperature for 24 hours. Then the solution was heated to reflux and thereafter was concentrated twice. The obtained upon cooling white crystals were crystallized from acetone:hexane 13:1 mixture.

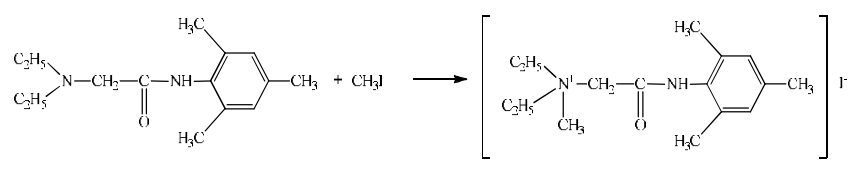

Fig. 4. Synthesis of N,

N-diethyl-2-(mesitylamino)-N-methyl-oxoethanaminium iodide (3).

The purified product was characterized by IR, NMR spectroscopy. In the IR spectrum a characteristic absorption band of the amide group is observed.

In the ${ }^{1} \mathrm{H}$ NMR spectrum the protons of methyl groups resonate at 1.28, 2.08, 2.19 and $3.15 \mathrm{ppm}$. Methylene provides peaks at 3.52 and $4.27 \mathrm{ppm}$. Peak with chemical shift of $6.87 \mathrm{ppm}$ corresponds to protons of benzene ring. The high-frequency peak at $9.81 \mathrm{ppm}$ can be attributed to a proton of an amide group.

In the carbon spectrum the signals of the methyl groups are found at 8.37-48.46 ppm. Methylene carbons resonates at 57.94 and 59.05 ppm. Low-intensity peaks at 129.02-136.78 ppm refer to the carbon atoms of the benzene ring. The atom of the carbonyl group gives a peak at $162.52 \mathrm{ppm}$. Here and for the further compounds mentioned in this paper the assignment of the signals was carried out with the involvement of the two-dimensional COSY spectroscopy and 
HMQC.

After working out the methodology of alkylation of trimecaine with methyl iodide, we moved to a more complex and interesting (in terms of potential pharmacological activity) reagent methoxyethoxyethyl bromide (Fig. 5). Introduction of methoxyethoxyethyl group to the nitrogen atom of the amino group impacts, for example, in the case of ambenoxane [19], muscle relaxant. It was expected that the long-chain alkyl bromide would be less active than methyl iodide, so the reaction time was increased to 3.5 hours. The solvent was evaporated and the product was dried under vacuum.

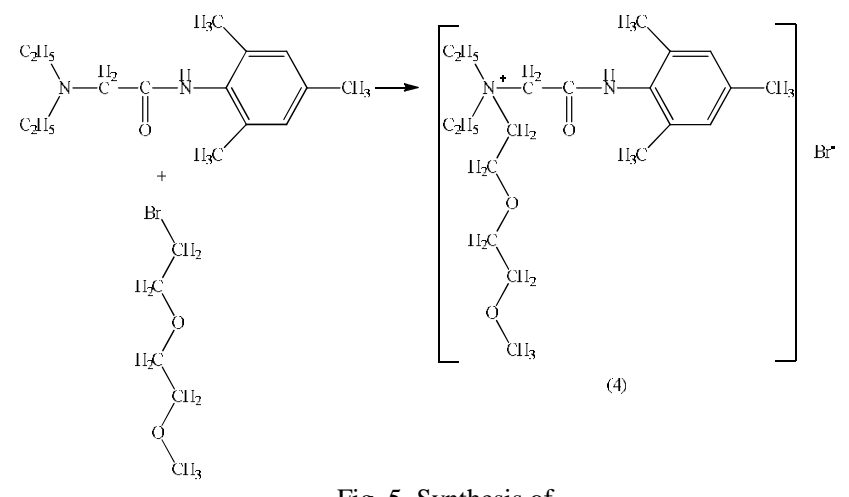

Fig. 5. Synthesis of

$\mathrm{N}, \mathrm{N}$-diethyl-2-mesytil-amino-N-(-2-(2-methoxyethoxy) ethyl) -2-oxo-ethaneammonium bromide (4).

The product was characterized by NMR spectroscopy. In the proton spectrum the peaks of the methyl groups of the alkyl substituents are observed at $1.10-3.38 \mathrm{ppm}$. Peaks at 3.45-3.81 ppm belong to protons of methylene groups at the nitrogen and oxygen heteroatoms. Peak with chemical shift of $6.88 \mathrm{ppm}$ can be attributed to equivalent protons of the aromatic ring, the most lowfield signal (10.28 ppm) corresponds to the proton of the amide group.

In the carbon spectrum most highfield signals at a frequency of $8.52,18.57,21.02$ and $56.42 \mathrm{ppm}$ can be attributed to the methyl carbon atoms. Methylene atoms resonate at 49.08, 59.23, 70.52 and $70.69 \mathrm{ppm}$. Aromatic atoms resonate at $129.02-137.27 \mathrm{ppm}$. The resonance line at $162.18 \mathrm{ppm}$ corresponds to the carbonyl atom.

Piromecaine is less studied in terms of the biological activity local anesthetic. In the form of a base it is also attractive for the synthesis of ionic compounds. For alkylation reaction commercially available form - piromecaine hydrochloride - was transferred to the form of a base by reaction with potassium carbonate, the product was isolated from the aqueous solution by extraction with benzene. We have carried out the alkylation of piromecaine with methyl iodide (Fig. 6). The reaction was carried out at $50{ }^{\circ} \mathrm{C}$ in acetonitrile medium with the following evaporation of the solvent and crystallization of the product from the mixture of THF and hexane.

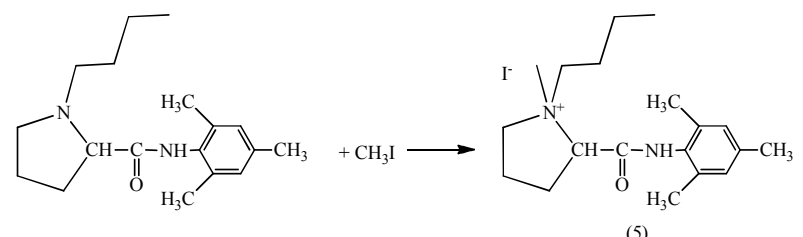

Fig. 6. Synthesis of 1-butyl -2-(mesytilcarbomoil)-1-methyl-pyrrolidinium-1 iodide (5).
The product was characterized by NMR spectroscopy. In the proton spectrum the peaks of the methyl and methylene groups of N-butyl radical observed at 0.89-1.64 and $3.65 \mathrm{ppm}$. The peaks at $1.85,2.26-2.42$ and $3.69 \mathrm{ppm}$ belong to protons of the five-membered heterocyclic ring. Methyl substituents of the aromatic ring resonate at 2.16-2.24 ppm. The peak at $6.86 \mathrm{ppm}$ can be attributed to the protons of the aromatic ring. The most high-frequency peak $(9.59 \mathrm{ppm})$ corresponds to the proton of the amide group.

In the carbon spectrum most highfield $(13.79,18.53,19.83$ and $21.04 \mathrm{ppm}$ ) peaks can be attributed to primary carbon atoms. Methylene atoms of $\mathrm{N}$-butyl substituent give signals at 20.77, 26.05 and 68.14 ppm. For atoms of nitrogen heterocycle the characteristic resonance line is at 20.37, 31.69, 63.37 and $73.44 \mathrm{ppm}$. The aromatic carbon atoms resonate at $129.13-137.65 \mathrm{ppm}$. The high-frequency peak with chemical shift of $164.61 \mathrm{ppm}$ refers to a keto group.

Further piromecaine was alkylated with ethyl iodide (Fig. 7). Interestingly that in contrast to the alkylation with methyl iodide, this reaction does not proceed at a temperature of $50^{\circ} \mathrm{C}$ in acetonitrile medium. We needed a change of solvent to toluene to carry out the reaction at $110^{\circ} \mathrm{C}$. The product is obtained in the form of insoluble in toluene white precipitation and separated from the reaction mixture by filtration.

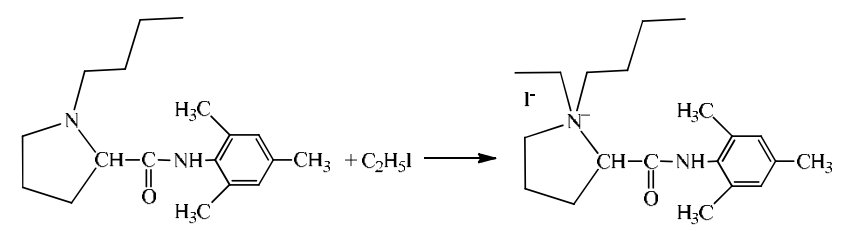

(6)

Fig. 7. Synthesis of 1-butyl -2- (mesytilcarbamoyl) -1-ethyl-pyrrolidinium-1 iodide (6).

The product was characterized by NMR spectroscopy. The signals of the methyl and methylene groups of N-butyl radical observed at $0.88-1.41,1.70$ and $3.73 \mathrm{ppm}$, while N-ethyl fragment protons resonate at $1.50\left(\mathrm{CH}_{3}\right)$ and $3.37 \mathrm{ppm}\left(\mathrm{CH}_{2}\right)$. The peaks at 1.83, 2.27-3.29 and $3.95 \mathrm{ppm}$ belong to the protons of the five-membered heterocyclic ring. Methyl substituents of the aromatic rings resonate at 2.15-2.23 ppm. The peak at $6.84 \mathrm{ppm}$ can be attributed to the protons of the aromatic ring. The most high-frequency peak $(9.75 \mathrm{ppm})$ corresponds to the proton of the amide group.

In the carbon spectrum most highfield $(9.21,13.53,20.65$, $21.02 \mathrm{ppm}$ ) peaks can be attributed to primary carbon atoms. Methylene atoms of N-butyl substituent give peaks at 18.52, 26.20 and $68.08 \mathrm{ppm}$. For atoms of nitrogen heterocycle characteristic resonance lines at 18.97, 30.90, 61.65 and $71.97 \mathrm{ppm}$ were observed. In the area of 129.00-137.56 ppm the characteristically resonating aromatic carbons are found. The high-frequency peak with chemical shift of $165.90 \mathrm{ppm}$ refers to a keto group.

\section{PREDiction OF the Biological ACtivity OF IONIC COMPOUNDS BASED ON N-ETHOXYETHYLPIPERIDINE, TRIMECAINE AND PIROMECAINE VIA PASS ONLINE}

PASS is an on-line service providing prediction a ranger of possible types of biologically activities of substances based 
on its structural formula, using a unified description of the chemical structure and the establishment of a universal mathematical algorithm of "structure-activity" relationship. The program predicts 783 kinds of biological activity by the structural formula of chemical substances, including the main and side pharmacological effects, mechanisms of action, mutagenicity, carcinogenicity, teratogenicity and embryotoxicity [19].

PASS is based on the analysis of the "structure-activity" relationship for substances from the reference selection, containing over 45000 different biologically active substances (known drugs and pharmacologically active compounds). The reference selection is constantly updated with new information on biologically active substances, which are selected from scientific publications as well as from numerous databases [20].

Herein (Table I) we report a PASS prediction of potential biological activity and potential toxic effects for the reported here $\mathrm{N}$-ethoxyethylpiperidine, trimecaine and piromecaine derivatives, where percentage corresponds to the probability of the effect. As it is seen from the Table I, N-ethoxyethylpiperidine derivatives (compounds (1) and (2)) showed spasmolytic, ovulation inhibition and progestin antagonist potential activity, from the other hand these two compounds showed possible teratogen and embryotoxic effects. Trimecaine derevatives (3) and (4) showed cardiotonic, spasmolytic and calcium channel activator effects with twitching, apnea and euphoria possible toxic effects. Piromecaine derivatives (5) and (6) showed gastrin inhibitor, membrane integrity antagonist and general pump inhibitor potential activity, as well as twitching, euphoria and sneezing possible toxic effects.

TABLE I: PREDICTION OF THE BIOLOGICAL ACTIVITY OF IONIC COMPOUNDS BASED ON N-ETHOXYETHYLPIPERIDINE, TRIMECAINE AND PIROMECAINE VIA PASS ONLINE

\begin{tabular}{|c|c|c|c|c|}
\hline \multirow[t]{2}{*}{ №* } & \multicolumn{2}{|c|}{ Potential activity (PA) } & \multicolumn{2}{|c|}{$\begin{array}{c}\text { Potential toxic effects } \\
\text { (PTE) }\end{array}$} \\
\hline & PA & Name of activity & PTE & $\begin{array}{c}\text { Name of toxic } \\
\text { effect }\end{array}$ \\
\hline \multirow[t]{5}{*}{1} & 0,700 & $\begin{array}{l}\text { Glyceryl-ether } \\
\text { monooxygenase } \\
\text { inhibitor }\end{array}$ & 0,722 & Weight gain \\
\hline & 0,651 & Ovulation inhibitor & 0,667 & Teratogen \\
\hline & 0,634 & Gestagen antagonist & 0,658 & Embryotoxic \\
\hline & 0,612 & Spasmolytic & 0,619 & $\begin{array}{l}\text { Reproductive } \\
\text { dysfunction }\end{array}$ \\
\hline & 0,577 & $\begin{array}{l}\text { Acylcarnitine } \\
\text { hydrolase inhibitor }\end{array}$ & 0,580 & Asthma \\
\hline \multirow[t]{6}{*}{2} & 0,757 & $\begin{array}{l}\text { Glyceryl-ether } \\
\text { monooxygenase } \\
\text { inhibitor }\end{array}$ & 0,700 & Weight gain \\
\hline & \multirow[t]{2}{*}{0,644} & \multirow[t]{2}{*}{ Gestagen antagonist } & 0,612 & $\begin{array}{l}\text { Reproductive } \\
\text { dysfunction }\end{array}$ \\
\hline & & & 0,508 & Teratogen \\
\hline & 0,608 & Ovulation inhibitor & 0,528 & Asthma \\
\hline & 0,567 & Spasmolytic & 0,492 & Embryotoxic \\
\hline & 0,556 & $\begin{array}{l}\text { Acylcarnitine } \\
\text { hydrolase inhibitor }\end{array}$ & 0,495 & Myoclonus \\
\hline \multirow[t]{4}{*}{3} & 0,926 & Cardiotonic & 0,851 & Twitching \\
\hline & 0,922 & Antiarrhythmic & 0,647 & $\begin{array}{l}\text { Methemoglobine } \\
\text { mia }\end{array}$ \\
\hline & 0,597 & $\begin{array}{l}\text { Sodium channel } \\
\text { blocker class Ib }\end{array}$ & 0,644 & Apnea \\
\hline & 0,611 & $\begin{array}{l}\text { Acetylcholine } \\
\text { neuromuscular }\end{array}$ & 0,608 & Euphoria \\
\hline
\end{tabular}

\begin{tabular}{|c|c|c|c|c|}
\hline & & blocking agent & & \\
\hline & 0,605 & $\begin{array}{l}\text { Calcium channel } \\
\text { (voltage-sensitive) } \\
\text { activator }\end{array}$ & 0,636 & Shivering \\
\hline \multirow[t]{7}{*}{4} & 0,969 & Cardiotonic & 0,624 & Euphoria \\
\hline & 0,960 & Antiarrhythmic & 0,565 & Sneezing \\
\hline & 0,656 & $\begin{array}{l}\text { Membrane integrity } \\
\text { antagonist }\end{array}$ & 0,545 & $\begin{array}{l}\text { Methemoglobine } \\
\text { mia }\end{array}$ \\
\hline & 0,532 & Spasmolytic & 0,517 & Laryngospasm \\
\hline & 0,536 & $\begin{array}{l}\text { Calcium channel } \\
\text { (voltage-sensitive) } \\
\text { activator }\end{array}$ & 0,524 & Apnea \\
\hline & 0,531 & $\begin{array}{l}\text { Acetylcholine } \\
\text { neuromuscular } \\
\text { blocking agent }\end{array}$ & 0,489 & $\begin{array}{l}\text { Allergic contact } \\
\text { dermatitis }\end{array}$ \\
\hline & 0,455 & Anesthetic & & \\
\hline \multirow[t]{7}{*}{5} & 0,672 & Gastrin inhibitor & 0,947 & Twitching \\
\hline & 0,645 & $\begin{array}{l}\text { Membrane integrity } \\
\text { antagonist }\end{array}$ & 0,721 & Euphoria \\
\hline & 0,618 & $\begin{array}{l}\text { General pump } \\
\text { inhibitor }\end{array}$ & 0,603 & Sneezing \\
\hline & 0,571 & Spasmolytic & 0,498 & Miotic \\
\hline & 0,511 & $\begin{array}{l}\text { Acetylcholine } \\
\text { neuromuscular } \\
\text { blocking agent }\end{array}$ & 0,542 & Shivering \\
\hline & 0,475 & $\begin{array}{l}\text { Nicotinic } \\
\text { alpha4beta4 receptor } \\
\text { agonist }\end{array}$ & & \\
\hline & 0,479 & $\begin{array}{l}\text { Kidney function } \\
\text { stimulant }\end{array}$ & & \\
\hline \multirow[t]{7}{*}{6} & 0,652 & $\begin{array}{l}\text { Glyceryl-ether } \\
\text { monooxygenase } \\
\text { inhibitor }\end{array}$ & 0,945 & Twitching \\
\hline & 0,633 & Gastrin inhibitor & 0,590 & Euphoria \\
\hline & 0,613 & $\begin{array}{l}\text { Membrane integrity } \\
\text { antagonist }\end{array}$ & 0,562 & Sneezing \\
\hline & 0,596 & $\begin{array}{l}\text { General pump } \\
\text { inhibitor }\end{array}$ & 0,453 & Miotic \\
\hline & 0,533 & Spasmolytic & 0,461 & Laryngospasm \\
\hline & 0,469 & $\begin{array}{l}\text { Acetylesterase } \\
\text { inhibitor }\end{array}$ & & \\
\hline & 0,318 & Anesthetic local & & \\
\hline
\end{tabular}

the numbers of compounds correspond to those mentioned in this paper

The next step of our research is a comparison of potential activities between two obtained compounds depending on the nature of a substituent. First, two compounds (1) and (2), which differs only in the nature of a substituent at nitrogen atom $\left(\mathrm{CH}_{3}\right.$ or $\left.\mathrm{C}_{2} \mathrm{H}_{5}\right)$ were compared. It can be observed that generally the potential biological activity of the compound (2) is higher which may correspond to the more strong inductive effect of the ethyl group (Fig. 8).

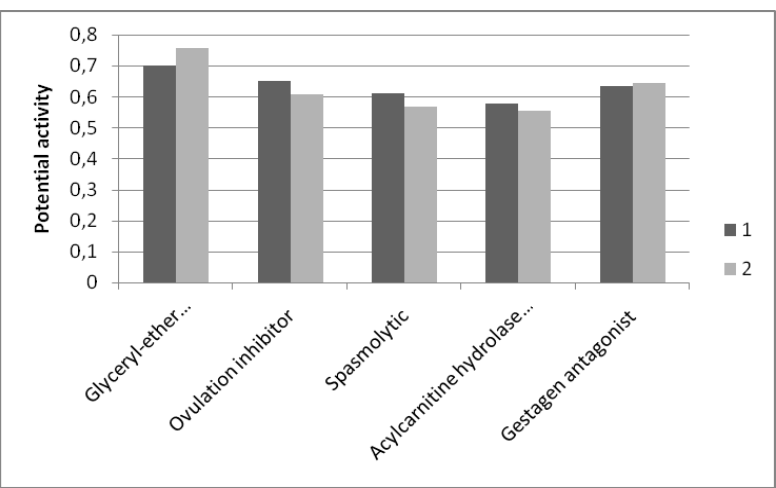

Fig. 8. Comparison of potential activities of compounds (1) and (2).

On the next charts (Fig. 9 and 10) the similar situation with 
changing of potential biological activity depending on the nature of a substituent at nitrogen atom for compounds (3), (4) and (5), (6), correspondingly, is observed.

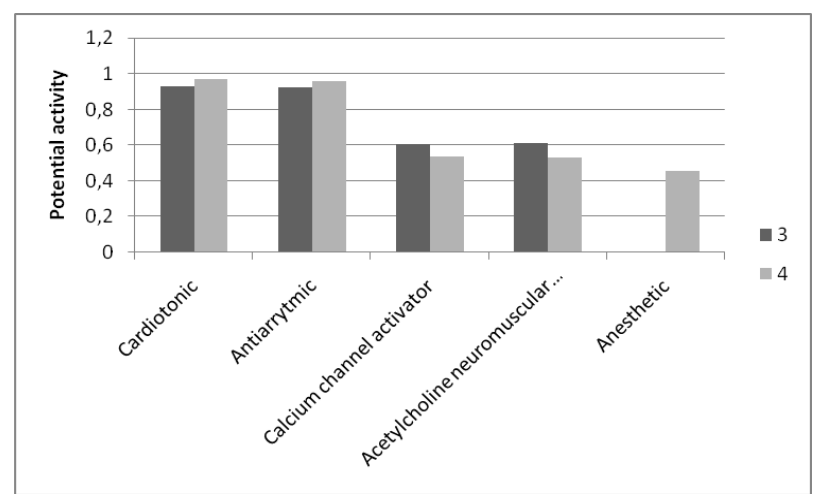

Fig. 9. Comparison of potential activities of compounds (3) and (4).

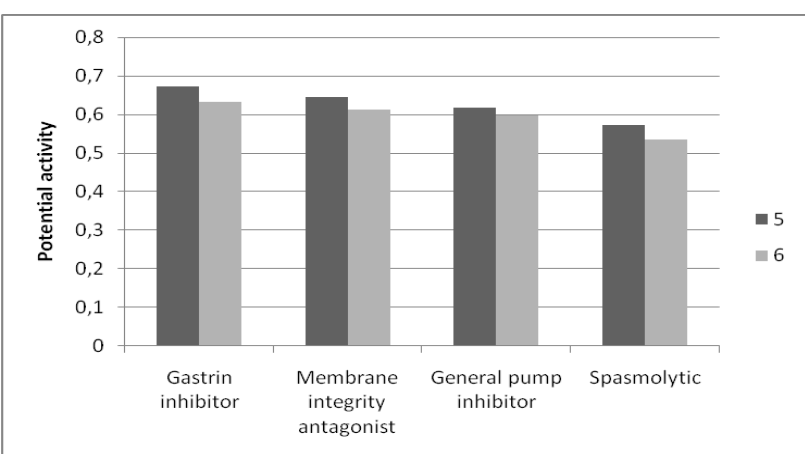

Fig. 10. Comparison potential activities of compounds (5) and (6).

\section{EXPERIMENTAL PART}

IR spectra were recorded on a spectrometer «Nicolet 5700 FT-IR» in the thin film. ${ }^{13} \mathrm{C}$ NMR spectra of synthesized compounds in $\mathrm{CDCl}_{3}$ at $25^{\circ} \mathrm{C}$ were recorded at «Mercury-300» («Varian» company) spectrometer. Monitoring of the reactions and the individual compounds were done by Thin Layer Chromatography (TLC) on $\mathrm{Al}_{2} \mathrm{O}_{3}$. Separation and purification of the substances was performed using crystallization from the corresponding solvents.

\section{1- (2-Ethoxyethyl) -4-acetyl-4-hydroxypiperidine}

$2.515 \mathrm{~g} \quad(0.01 \mathrm{~mol})$ of 1-(2-ethoxyethyl) -4-acetyl-4-hydroxypiperidine hydrochloride was dissolved in $100 \mathrm{ml}$ water under slight warming and $\mathrm{K}_{2} \mathrm{CO}_{3}$ was added until $\mathrm{pH}$ is reached 9. Then obtained base extracted with benzene. After drying the benzene solution with $\mathrm{CaCl}_{2}$ it was evaporated to dryness. Yield $1.94 \mathrm{~g}(89.5 \%)$ of 1(2-ethoxyethyl)-4-acetyl-4-hydroxypiperidine as a white solid $\mathrm{T}_{\text {melt }}=80.2-80.6{ }^{\circ} \mathrm{C} .{ }^{13} \mathrm{C} \mathrm{NMR}\left(\mathrm{CDCl}_{3}\right) \delta$, ppm: $87.05(\mathrm{~s}$, $\mathrm{HC} \equiv \mathrm{C}-) ; 72.91\left(\mathrm{sp}^{3} \mathrm{C}\right) ; 68.36\left(\mathrm{~s}, \mathrm{CH}_{3} \mathrm{CH}_{2} \mathrm{OCH}_{2} \mathrm{CH}_{2}\right) ; 68.55$ (s, $\left.\mathrm{CH}_{3} \mathrm{CH}_{2} \mathrm{OCH}_{2} \mathrm{CH}_{2}\right) ; 57.62\left(\mathrm{~s}, \mathrm{CH}_{3} \mathrm{CH}_{2} \mathrm{OCH}_{2} \mathrm{CH}_{2}\right) ; 50.60$ $\left(\mathrm{sp}^{3} \underline{\mathrm{C}}-\mathrm{N}\right) ; 38.97\left(\mathrm{sp}^{3} \mathrm{C}-\mathrm{C}\right) ; 15.26\left(\mathrm{~s}, \underline{\mathrm{CH}_{3}} \mathrm{CH}_{2} \mathrm{OCH}_{2} \mathrm{CH}_{2}\right) .{ }^{1} \mathrm{H}$ NMR $\left(\mathrm{CDCl}_{3}\right) \quad \delta, \quad$ ppm: 3.55, 3.54, $3.52 \quad(\mathrm{t}$, $\left.\mathrm{CH}_{3} \mathrm{CH}_{2} \mathrm{OCH}_{2} \mathrm{CH}_{2}\right) ; \quad 3.50, \quad 3.49, \quad 3.47, \quad 3.45 \quad$ (q, $\left.\mathrm{CH}_{3} \mathrm{CH}_{2} \mathrm{OCH}_{2} \mathrm{CH}_{2}\right) ; 2.71\left(\mathrm{H}_{2}-\mathrm{C}-\mathrm{N}\right.$ in ring $) ; 2.61,2.59,2.58(\mathrm{t}$, $\left.\mathrm{CH}_{3} \mathrm{CH}_{2} \mathrm{OCH}_{2} \underline{\mathrm{CH}}_{2}\right) ; 2.49$ (s, $\left.\underline{\mathrm{HC}} \equiv \mathrm{C}-\right) ; 1.92,1.86\left(\underline{\mathrm{H}}_{2}-\mathrm{C}-\mathrm{C}\right.$ in ring); $1.20,1.18,1.16\left(\mathrm{t}, \mathrm{CH}_{3} \mathrm{CH}_{2} \mathrm{OCH}_{2} \mathrm{CH}_{2}\right)$. IR ( $\left.\mathrm{KBr}\right), \mathrm{cm}^{-1}$ : $3238(\mathrm{O}-\mathrm{H}) ; 2097$ (C $\equiv \mathrm{C}), 1288,1257,1226(\mathrm{C}-\mathrm{O}), 880(\mathrm{C}-\mathrm{N})$. Calculated for $\mathrm{C}_{11} \mathrm{H}_{19} \mathrm{NO}_{2}, \%$ : C, 66.97; H, 9.71; N, 7.10; O, 16.22. Found, \%: C, 67.03; H, 9.80 .

\section{1-(2-Ethoxyethyl)}

\section{-4-ethynyl-4-hydroxy-1-methylpiperidine iodide (1)}

$2.15 \mathrm{~g} \quad(0.01 \mathrm{~mol})$ of 1-(2-ethoxyethyl) -4-acetyl-4-hydroxypiperidine was dissolved in $40 \mathrm{ml}$ of acetonitrile and a solution of $0.705 \mathrm{ml}(0.011 \mathrm{~mol})$ of methyl iodide in $5 \mathrm{ml}$ acetonitrile was added. The solution was kept under reflux for $1 \mathrm{~h}$, thereafter acetonitrile was removed by evaporation. $2.39 \mathrm{~g}$ of 1-(2-ethoxyethyl) -4-ethynyl-4-hydroxy-1-methylpiperidine iodide (1) were obtained as a pale yellow viscous mass. For purification it was crystallized from acetone to obtaine white crystals. Yield $67.0 \%$. M.p. $120-121^{\circ} \mathrm{C}$. IR (KBr), cm ${ }^{-1}: 3266(\mathrm{O}-\mathrm{H}) ; 2109$ $(\mathrm{C} \equiv \mathrm{C}), 1276,1192,1173(\mathrm{C}-\mathrm{O}), 859(\mathrm{C}-\mathrm{N})$. Calculated for $\mathrm{C}_{12} \mathrm{H}_{22} \mathrm{NO}_{2} \mathrm{I}, \%$ : C, 42.49; H, 6.54; N, 4.13. Found, \%: C, 44.67; H, 6.10. Mass-spectrum: $212.2\left(\mathrm{C}_{12} \mathrm{H}_{22} \mathrm{NO}_{2}{ }^{+}\right)$.

\section{1-(2-Ethoxyethyl)}

\section{-4-ethynyl-4-hydroxy-1-ethyl-piperidinium iodide (2)}

$2.15 \mathrm{~g} \quad(0.01 \mathrm{~mol})$ of 1 - (2-ethoxyethyl) -4-acetyl-4-hydroxypiperidine were dissolved in $40 \mathrm{ml}$ of acetonitrile and added into solution of $0.95 \mathrm{ml}(0.011 \mathrm{~mol})$ ethyl iodide in $5 \mathrm{ml}$ acetonitrile. Mixture was boiled for 3.5 hours under the reflux; the acetonitrile was removed by evaporation. The product 1-(2-ethoxyethyl) -4-ethynyl-4-hydroxy-1-ethyl-piperidinium iodide (2) was obtained as a yellow liquid, which doesn't get solid at $-19^{\circ} \mathrm{C}$, yield was not determined, for further studies the product was used without further purification. IR $(\mathrm{KBr}), \mathrm{cm}^{-1}: 3239(\mathrm{O}-\mathrm{H})$; $2097(\mathrm{C} \equiv \mathrm{C}), 1263,1227$ (C-O), $859(\mathrm{C}-\mathrm{N}) .{ }^{1} \mathrm{H}$ NMR $\left(\mathrm{CDCl}_{3}\right)$ $\delta$, ppm: 3.91, $3.73\left(\underline{\mathrm{H}}_{2}-\mathrm{C}-\mathrm{N}^{+}\right.$in ring $) ; 3.87$ $\left(\mathrm{CH}_{3} \mathrm{CH}_{2} \mathrm{OCH}_{2} \mathrm{CH}_{2}\right) ; \quad 3.71 \quad\left(\mathrm{CH}_{3} \mathrm{CH}_{2} \mathrm{OCH}_{2} \underline{\mathrm{C}}_{2}\right) ; 3.69$ $\left(\mathrm{N}^{+}-\underline{\mathrm{C}}_{2} \mathrm{CH}_{3}\right) ; \quad 3.58, \quad 3.56, \quad 3.55, \quad 3.53, \quad 3.51 \quad$ (p, $\left.\mathrm{CH}_{3} \underline{\mathrm{C}}_{2} \mathrm{OCH}_{2} \mathrm{CH}_{2}\right) ; 2.77,2.75$ ( $\left.\underline{\mathrm{HC}} \equiv \mathrm{C}-\right) ; 2.52,2.49,2.45$, $2.26\left(\mathrm{H}_{4,2}\right) ; 2.0\left(\mathrm{~s}, \mathrm{H}_{7}\right) ; 1.46,1.44,1.42,1.40\left(\mathrm{q}, \mathrm{N}^{+}-\mathrm{CH}_{2} \mathrm{CH}_{3}\right)$; $1.19,1.17,1.16\left(\mathrm{t}, \mathrm{CH}_{3} \mathrm{CH}_{2} \mathrm{OCH}_{2} \mathrm{CH}_{2}\right) . \mathrm{C}^{13} \mathrm{AMP}\left(\mathrm{CDCl}_{3}\right) \delta$, ppm: $84.85 \quad$ (s, $\quad$ HC $\equiv \underline{C}-) ; 74.41 \quad$ (s, $\mathrm{HC} \equiv \mathrm{C}-) ; 67.33$ $\left(\mathrm{sp}^{3} \mathrm{CH}_{2}-\mathrm{N}^{+}\right) ; \quad 63.90 \quad\left(\mathrm{~s}, \quad \mathrm{CH}_{3} \mathrm{CH}_{2} \mathrm{OCH}_{2} \mathrm{CH}_{2}\right) ; 63.80 \quad$ (s, $\mathrm{CH}_{3} \mathrm{CH}_{2} \mathrm{OCH}_{2} \mathrm{CH}_{2}$ ); 62,76 (s, $\left.\mathrm{CH}_{3} \mathrm{CH}_{2} \mathrm{OCH}_{2} \mathrm{CH}_{2}\right) ; 56.20$ (s, $\mathrm{N}^{+}-\underline{\mathrm{CH}}_{2} \mathrm{CH}_{3}$ ); 33.21 (s, $\mathrm{CH}_{2}$ in ring); 29.90 ( $\mathrm{sp}^{3} \mathrm{C}$ in ring); $15.20\left(\mathrm{~d}, \mathrm{C}_{11}\left(\mathrm{~N}^{+}-\mathrm{CH}_{2} \underline{\mathrm{CH}}_{3}\right) ; \mathrm{C}_{7}\right) ; 8.65\left(\mathrm{~s}, \mathrm{CH}_{3} \mathrm{CH}_{2} \mathrm{OCH}_{2} \mathrm{CH}_{2}\right)$. Calculated for $\mathrm{C}_{13} \mathrm{H}_{24} \mathrm{NO}_{2} \mathrm{I}, \%$ : C, 44.20; H, 6.85; N, 3.97 . Found, \%: C, 44.35; H, 6.78. Mass-spectrum: 226.2 $\left(\mathrm{C}_{13} \mathrm{H}_{22} \mathrm{NO}_{2}^{+}\right)$.

\section{Trimecaine}

$2.054 \mathrm{~g}(0.00703 \mathrm{~mol})$ of trimecaine hydrochloride was dissolved in $15 \mathrm{ml}$ of water. The solution had $\mathrm{pH}=6.5$. $\mathrm{K}_{2} \mathrm{CO}_{3}$ was added until $\mathrm{pH}=8-9$. Extraction was performed three times with benzene $(15 \mathrm{ml})$. The resulting extract was dried with anhydrous calcium chloride for 8 hours. The solvent was removed by simple distillation. The product was dried for two hours in vacuum at $70^{\circ} \mathrm{C}$. Yield of trimecaine is $1.492 \mathrm{~g}(85.57 \%) .{ }^{13} \mathrm{C} \mathrm{NMR}\left(\mathrm{CDCl}_{3}\right) \delta, \mathrm{ppm}: 170.57$ (s, $\mathrm{C}=\mathrm{O}) ; 136.81$ (s, $\underline{\mathrm{C}}-\mathrm{CH}_{3}$ aromatic); 134.93 (s, $\underline{\mathrm{C}}-\mathrm{CH}_{3}$ aromatic); $131.33 \quad$ (s, $\underline{\mathrm{C}}-\mathrm{NH}$ aromatic); $129.03 \quad\left(\mathrm{sp}^{2} \underline{\mathrm{C}}\right.$

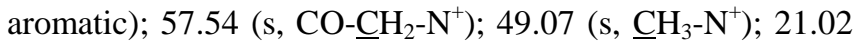
$\left(\mathrm{sp}^{3}, \mathrm{CH}_{3}\right) ; 18.56\left(\mathrm{~s}, \mathrm{CH}_{3}\right) ; 12.77\left(\mathrm{~s}, \mathrm{CH}_{3}-\mathrm{CH}_{2}-\mathrm{N}^{+}\right) .{ }^{1} \mathrm{H}$ NMR $\left(\mathrm{CDCl}_{3}\right) \delta$, ppm: 8.84 (s, N-H); 6.89 (s, H aromatic); 3.21 (s, $\left.\mathrm{CO}-\mathrm{CH}_{2}-\mathrm{N}^{+}\right) ; 2.65,2.66,2.68,2.70\left(\mathrm{q}, \mathrm{C}_{\text {aromatic }}-\mathrm{CH}_{3}\right) ; 2.25(\mathrm{~s}$, $\left.\mathrm{C}_{\underline{3}}\right) ; 2.18\left(\mathrm{C}_{3}\right) ; 1.14,1.12,1.10\left(\mathrm{t}, \mathrm{C}_{3}{ }_{3}-\mathrm{N}^{+}\right)$. Calculated for $\mathrm{C}_{15} \mathrm{H}_{24} \mathrm{~N}_{2} \mathrm{O}, \%$ : C, 72.54; H, 9.74; N, 11.28; O, 6.44 . Found \%: C, 72.04; H, 9.86. 
N,N-Diethyl-2-(mesitylamino)-N-methyl-oxoethanamin ium iodide (3)

$1.492 \mathrm{~g}(0.006 \mathrm{~mol})$ of trimecain were dissolved in $5 \mathrm{ml}$ of acetonitrile. $0.41 \mathrm{ml}(0.007 \mathrm{~mol})$ of methyl iodide were dissolved in $5 \mathrm{ml}$ of acetonitrile. After mixing together the resulting solution was left for $24 \mathrm{hrs}$. Then the volume of the solution was reduced 2-3 times with evaporation. After cooling white crystals were formed. $(2.148 \mathrm{~g})$. Purification was performed by crystallization from acetone: hexane (13:1) solution. Yield $1.347 \mathrm{~g}(57.56 \%)$. M.p. $207.7^{\circ} \mathrm{C}$. IR (KBr), $\mathrm{cm}^{-1}: 3173(\mathrm{~N}-\mathrm{H}) 1692(\mathrm{C}=\mathrm{O}$ amide $), 1527\left(\mathrm{C}_{\text {arom }}=\mathrm{C}_{\text {arom }}\right) .{ }^{13} \mathrm{C}$ NMR (DMSO-d $\left.{ }_{6}, 30^{\circ} \mathrm{C}\right) \delta$, ppm: $162.52(\mathrm{~s}, \mathrm{C}=\mathrm{O}) ; 136.78(\mathrm{~s}$, $\left.\mathrm{CH}_{3}\right) ; 135.20\left(\mathrm{~s}, \mathrm{CH}_{3}\right) ; 131.27$ (s, $\left.\underline{\mathrm{C}}_{\text {aromatic }}-\mathrm{NH}\right) ; 129.02$ (s, $\left.\mathrm{C}_{\text {aromatic }}\right) ; 59.05\left(\mathrm{~s}, \mathrm{CO}-\underline{\mathrm{CH}}_{2}-\mathrm{N}^{+}\right) ; 57.94\left(\mathrm{~s}, \mathrm{~N}^{+}-\underline{\mathrm{CH}}_{2}-\mathrm{CH}_{3}\right)$; $48.46\left(\mathrm{~s}, \quad \mathrm{~N}^{+}-\underline{\mathrm{CH}}_{3}\right) ; 21.02\left(\mathrm{~s}, \mathrm{C}_{\text {aromatic }}-\underline{\mathrm{CH}}_{3}\right) ; 18.55(\mathrm{~s}$, $\left.\mathrm{C}_{\text {aromatic }}-\underline{\mathrm{CH}}_{3}\right) ; 8.37\left(\mathrm{~s}, \mathrm{~N}^{+}-\mathrm{CH}_{2}-\underline{\mathrm{CH}}_{3}\right) .{ }^{1} \mathrm{H} \mathrm{NMR} \delta$, ppm: 9.81 (s, $\mathrm{N}-\mathrm{H}) ; 6.87$ (s, $\mathrm{H}_{\text {aromatic }}$ ); 4.27 (s, $\left.\mathrm{CO}-\mathrm{CH}_{2}-\mathrm{N}^{+}\right) ; 3.52,3.54$, $3.56\left(\mathrm{~N}^{+}-\underline{\mathrm{C}}_{2}-\mathrm{CH}_{3}\right) ; 3.15\left(\mathrm{~s}, \mathrm{~N}^{+}-\underline{\mathrm{C}}_{3}\right) ; 2.19\left(\mathrm{~s}, \mathrm{C}_{\text {aromatic }}-\underline{\mathrm{CH}}_{3}\right)$; 2.08 (s, $\left.\mathrm{C}_{\text {aromatic }}-\underline{\mathrm{CH}}_{3}\right) ; 1.30,1.28,1.26\left(\mathrm{t}, \mathrm{N}^{+}-\mathrm{CH}_{2}-\underline{\mathrm{CH}}_{3}\right)$. Mass-spectrum: cation $\mathrm{C}_{16} \mathrm{H}_{27} \mathrm{~N}_{2} \mathrm{O}^{+}$, 263.2. Calculated for $\mathrm{C}_{16} \mathrm{H}_{27} \mathrm{~N}_{2} \mathrm{OI}, \%$ : C, 49.24; H, 6.97; N, 7.18; O, 4.1; I, 32.51. Found \%: C, 48.96; H, 7.01.

N,N-Diethyl-2-mesitylamino-N-(-2-(2-methoxyethoxy) ethyl) -2-oxo-ethaneammonium bromide (4)

$2.056 \mathrm{~g}(0.008 \mathrm{~mol})$ of trimecaine were dissolved in $20 \mathrm{ml}$ of acetonitrile. This solution was added to $1.6 \mathrm{ml}(0.009 \mathrm{~mol})$ of methoxyethoxyethyl bromide. The resulting solution was heated to reflux for 3.5 hours. The solvent was removed by evaporation. The yellow viscous mass was obtained. The yield was not determined, for further studies it was used without further purification. ${ }^{13} \mathrm{C}$ NMR $\delta$, ppm: 162.18 (s, $\mathrm{C}=\mathrm{O}) ; \quad 137.06, \quad 134.85, \quad 131.75,129.02 \quad\left(\mathrm{C}_{\text {arom }}\right) ; 70.87$ $\left(\mathrm{O}-\mathrm{CH}_{2}-\mathrm{CH}_{2}-\mathrm{O}-\mathrm{CH}_{3}\right) ; \quad 70.69 \quad\left(\mathrm{~N}-\mathrm{CH}_{2} \mathrm{CH}_{2}-\mathrm{O}\right) ; \quad 70.52$ $\left(\mathrm{O}-\mathrm{CH}_{2}-\mathrm{CH}_{2}-\mathrm{O}-\mathrm{CH}_{3}\right) ; \quad 64.81 \quad\left(\mathrm{~N}-\underline{C H}_{2}-\mathrm{C}=\mathrm{O}\right) ; \quad 59.20$ $\left(\mathrm{N}-\mathrm{CH}_{2} \mathrm{CH}_{2}-\mathrm{O}\right) ; 56.42\left(\mathrm{O}-\mathrm{CH}_{3}\right) ; 49.08\left(\mathrm{~N}-\mathrm{CH}_{2} \mathrm{CH}_{3}\right) ; 21.02$ $\left(n-\mathrm{CH}_{3}\right), 18.74\left(o-\mathrm{CH}_{3}\right), 8.52\left(\mathrm{~N}-\mathrm{CH}_{2} \mathrm{CH}_{3}\right) .{ }^{1} \mathrm{H} \mathrm{NMR} \delta$, ppm: 10.28 (s, N- - ) ; 6.86 (d, $\mathrm{H}_{\text {aromatic }}$ ); 3.81-3.45 (m, $\mathrm{CH}_{2}-\mathrm{O}$, $\left.\mathrm{CH}_{2}-\mathrm{N}\right) ; 3.38\left(\mathrm{O}-\mathrm{CH}_{3}\right) ; 2.22\left(n-\mathrm{CH}_{3}\right) ; 2.16\left(o-\mathrm{CH}_{3}\right) ; 1.34(\mathrm{t}$, $\mathrm{N}-\mathrm{CH}_{2} \mathrm{CH}_{3}$ ). Calculated for $\mathrm{C}_{20} \mathrm{H}_{35} \mathrm{~N}_{2} \mathrm{O}_{3} \mathrm{Br}, \%$ : C, 55.68; H, 8.18; N, 6.49; O, 11.13; Br, 18.52. Found \%: C, 54.99; H, 8.31.

\section{Piromecaine}

$2.143 \mathrm{~g}$ of piromecaine hydrochloride was dissolved in 25 $\mathrm{ml}$ of water under slight heating. After cooling into the solution was $\mathrm{K}_{2} \mathrm{CO}_{3}$ added until $\mathrm{pH}=9$. Extraction was performed three times with $15 \mathrm{ml}$ benzene with further benzene distillation. The compound was dried under vacuum at $65^{\circ} \mathrm{C}$ for one hour. Yield $1.842 \mathrm{~g}(96.88 \%)$ as white crystals with cream tint. M.p. $70-75^{\circ} \mathrm{C} .{ }^{13} \mathrm{C} \mathrm{NMR}\left(\mathrm{CDCl}_{3}\right) \delta$, ppm: $165.90(\mathrm{~s}, \mathrm{C}=\mathrm{O}) ; 137.56 \quad\left(\mathrm{~s}, \underline{\mathrm{C}}_{\text {aromatic }}-\mathrm{CH}_{3}\right) ; 134.78$ (s, $\left.\underline{\mathrm{C}}_{\text {aromatic }}-\mathrm{CH}_{3}\right) ; 129.87$ (s, $\left.\underline{\mathrm{C}}_{\text {aromatic }}-\mathrm{NH}\right) ; 129.12$ (d, $\left.\underline{\mathrm{C}}_{\text {aromatic }}\right)$; 71.97 (s, $\mathrm{C}-\mathrm{CO}) ; 68.08$ (s, $\left.\mathrm{CH}_{3} \mathrm{CH}_{2} \mathrm{CH}_{2} \mathrm{CH}_{2}\right) ; 61.65$ (s, $\left.\mathrm{N}^{+}-\underline{\mathrm{CH}}_{2}\right) ; 55.79\left(\mathrm{~s}, \mathrm{~N}^{+}-\underline{\mathrm{CH}}_{3}\right) ; 30.90\left(\mathrm{CH}_{2}\right.$ in ring); 26.20 (s, $\left.\mathrm{CH}_{3} \mathrm{CH}_{2} \mathrm{CH}_{2} \mathrm{CH}_{2}\right) ; 21.02 \quad\left(\mathrm{~s}, \mathrm{C}_{\text {aromatic }}-\mathrm{CH}_{3}\right) ; 20.65 \quad(\mathrm{~s}$, $\left.\mathrm{C}_{\text {aromatic }}-{ }^{-} \mathrm{H}_{3}\right) ; 13.53\left(\mathrm{~s}, \underline{\mathrm{CH}}_{3} \mathrm{CH}_{2} \mathrm{CH}_{2} \mathrm{CH}_{2}\right) .{ }^{1} \mathrm{H} \mathrm{NMR}\left(\mathrm{CDCl}_{3}\right)$ $\delta$, ppm: 9.75 (d, N- $\underline{\mathrm{H}}$ ); 6.84 (d, $\mathrm{H}_{\text {aromatic }}$ ); 3.95 (q, C$\left.-\mathrm{CO}\right)$; $3.73\left(\mathrm{CH}_{2}-\mathrm{N}^{+}\right) ; 3.56\left(\mathrm{t}, \mathrm{C}_{2}-\mathrm{N}^{+}\right) ; 2.76,2.74\left(\mathrm{~N}^{+}-\mathrm{CH}_{2}\right) ; 2.39$ $\left(\mathrm{CH}-\underline{\mathrm{H}}_{2}-\mathrm{CH}_{2}\right) ; 2.23$ (s, $\left.\mathrm{C}_{\text {aromatic }}-\underline{\mathrm{CH}}_{3}\right) ; 2.15$ (s, $\left.\mathrm{C}_{\text {aromatic }}-\underline{\mathrm{CH}}_{3}\right)$; $1.83,1.84\left(\mathrm{~d}, \mathrm{CH}_{2}-\mathrm{CH}_{2}-\mathrm{CH}_{2}\right) ; 1.70\left(\mathrm{~s}, \mathrm{~N}^{+}-\mathrm{CH}_{2}-\mathrm{CH}_{2}\right) ; 1.37$ $\left(\mathrm{N}^{+}-\mathrm{CH}_{2}-\mathrm{CH}_{2}-\underline{\mathrm{H}}_{2}-\mathrm{CH}_{3}\right) ; 0.96$ (duplet of triplets,
$\left.\mathrm{N}^{+}-\mathrm{CH}_{2}-\mathrm{CH}_{2}-\mathrm{CH}_{2}-\mathrm{CH}_{3}\right)$. Calculated for $\mathrm{C}_{18} \mathrm{H}_{28} \mathrm{~N}_{2} \mathrm{O}$, \%: C, 74.96; H, 9.79; N, 9.71; O, 5.55. Found \%: C, 74.77; H, 9.90. 1-Butyl -2-(mesitylcarbamoyl)-1-methyl-pyrrolidinium-1 iodide (5)

$1.843 \mathrm{~g}(0.0064 \mathrm{~mol})$ of piromecaine were dissolved in 40 $\mathrm{ml}$ of acetonitrile. $0.438 \mathrm{ml}(0.007 \mathrm{~mol})$ of methyl iodide were dissolved in $5 \mathrm{ml}$ of acetonitrile. Two solutions were mixed together and were heated for 30 minutes at $50^{\circ} \mathrm{C}$. Then the resulting solution was evaporated to half volume. After cooling the crystals were obtained. The resulting yellow crystals were crystallized from THF : hexane (19:7). Yield $0.0414 \mathrm{~g}(1.5 \%)$ as yellowish crystals. M.p. $136-140^{\circ} \mathrm{C}$.

${ }^{13} \mathrm{C} \mathrm{NMR}\left(\mathrm{CDCl}_{3}\right) \delta$, ppm: $164.61(\mathrm{~s}, \mathrm{C}=\mathrm{O}) ; 137.65$ (s, $\left.\underline{\mathrm{C}}_{\text {aromatic }}-\mathrm{CH}_{3}\right) ; \quad 134.70 \quad\left(\mathrm{~d}, \quad \underline{\mathrm{C}}_{\text {aromatic }}-\mathrm{CH}_{3}\right) ; 129.96 \quad$ (s, $\left.\underline{\mathrm{C}}_{\text {aromatic }} \mathrm{NH}\right) ; 129.13$ (d, $\left.\mathrm{C}_{\text {aromatic }}\right) ; 73.44$ (s, $\left.\underline{\mathrm{C}}-\mathrm{CO}\right) ; 68.47$ (s, $\left.\mathrm{CH}_{3} \mathrm{CH}_{2} \mathrm{CH}_{2} \mathrm{CH}_{2}\right) ; 63.49$ (s, $\left.\mathrm{CH}_{2}-\underline{C H}_{2}-\mathrm{N}^{+}\right) ; 45.05$ (s, N $\left.\mathrm{N}^{+}-\mathrm{CH}_{3}\right)$; 31.69 (s, $\mathrm{CH}_{2}-\mathrm{CH}_{2}-\mathrm{CH}_{2}$ ); 25.61 (d/s, $\mathrm{CH}_{3} \mathrm{CH}_{2} \mathrm{CH}_{2} \mathrm{CH}_{2}$ ); 20.37 (s, $\left.\underline{\mathrm{C}}_{\text {aromatic }}-\mathrm{CH}_{3}\right) ; 19.83$ (s, $\left.\mathrm{CH}_{3} \underline{\mathrm{CH}}_{2} \mathrm{CH}_{2} \mathrm{CH}_{2}\right) ; 18.53$ (s, $\left.\underline{\mathrm{C}}_{\text {aromatic }}-\mathrm{CH}_{3}\right) ; 13.79\left(\mathrm{~s}, \underline{\mathrm{CH}_{3}} \mathrm{CH}_{2} \mathrm{CH}_{2} \mathrm{CH}_{2}\right) .{ }^{1} \mathrm{H} \mathrm{NMR}\left(\mathrm{CDCl}_{3}\right)$

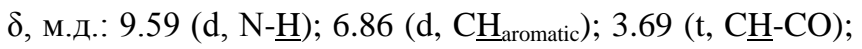
3.65 (duplet of triplets, $\left.\mathrm{CH}_{2}-\mathrm{N}^{+}\right) ; 3.29\left(\mathrm{~d}, \mathrm{C}_{\underline{3}}-\mathrm{N}^{+}\right) ; 2.42$ $\left(\mathrm{N}^{+}-\underline{\mathrm{H}}_{2}\right) ; 2.38\left(\mathrm{CH}-\underline{\mathrm{CH}}_{2}-\mathrm{CH}_{2}\right) ; 2.24\left(\mathrm{~s}, \mathrm{C}_{\text {aromatic }}-\underline{\mathrm{C}}_{3}\right) ; 2.22(\mathrm{~s}$, $\left.\mathrm{C}_{\text {aromatic }}-\underline{\mathrm{C}}_{3}\right) ; 2.16\left(\mathrm{~s}, \overline{\mathrm{C}}_{\text {aromatic }}-\underline{\mathrm{C}}_{3}\right) ; 1.85\left(\mathrm{t}, \mathrm{CH} 2-\mathrm{CH}_{2}-\mathrm{CH}_{2}\right)$; 1.64 (s, $\left.\mathrm{CH}_{2}-\mathrm{CH}_{2}-\mathrm{N}^{+}\right) ; 1.48 \quad\left(-\mathrm{CH}_{2}-\mathrm{CH}_{2}-\mathrm{CH}_{2}-\mathrm{N}^{+}\right) ; 0.99$ $\left(\mathrm{CH}_{3}-\mathrm{CH}_{2}-\mathrm{CH}_{2}-\mathrm{CH}_{2}-\mathrm{N}^{+}\right)$. Calculated for $\mathrm{C}_{19} \mathrm{H}_{31} \mathrm{~N}_{2} \mathrm{OI}, \%$ : C, 53.02; H, 7.27; N, 6.51; I, 29.48; O, 3.72. Found \%: C, 53.24; H, 7.18.

\section{1-Butyl $-2-$ \\ -1-ethyl-pyrrolidinium-1 iodide (6)}

$3.715 \mathrm{~g}(0.0129 \mathrm{~mol})$ of piromecain were dissolved in 40 $\mathrm{ml}$ of acetonitrile. $2.28 \mathrm{ml}(0.0284 \mathrm{~mol})$ of ethyl iodide were dissolved in $5 \mathrm{ml}$ of acetonitrile. Two solutions were mixed together and were heated for 30 minutes at $50^{\circ} \mathrm{C}$. After the solvent was distilled off the sand-colored viscous wax-like substance was obtained (3.858 g). It was dissolved in $25 \mathrm{ml}$ of toluene and refluxed for 11 hours. After cooling to $4{ }^{0} \mathrm{C}$ the crystals (white slurry) were precipitated and then filtered off. The product was dried under vacuum for 40 minutes. Yield 0.447 g (7.8\%). M.p. $193-196{ }^{\circ} \mathrm{C} .{ }^{13} \mathrm{C} \mathrm{NMR}\left(\mathrm{CDCl}_{3}\right) \delta$, ppm: $165.90(\mathrm{~s}, \mathrm{C}=\mathrm{O}) ; 137.56\left(\mathrm{~s}, \underline{\mathrm{C}}_{\text {aromatic }}-\mathrm{CH}_{3}\right) ; 134.78(\mathrm{~d}$, $\left.\underline{\mathrm{C}}_{\text {aromatic }}-\mathrm{CH}_{3}\right) ; 129.87$ (s, $\left.\underline{\mathrm{C}}_{\text {aromatic }}-\mathrm{NH}\right) ; 129.12$ (d, $\left.\mathrm{C}_{\text {aromatic }}\right)$; 71.97 (s, $\underline{\mathrm{C}}-\mathrm{CO}) ; 68.08$ (s, $\mathrm{CH}_{3} \mathrm{CH}_{2} \mathrm{CH}_{2} \mathrm{CH}_{2}$ ); 61.65 (s, $\left.\mathrm{CH}_{2}-\mathrm{CH}_{2}-\mathrm{N}^{+}\right) ; \quad 55.79 \quad\left(\mathrm{~s}, \quad \mathrm{CH}_{3}-\underline{\mathrm{CH}}_{2}-\mathrm{N}^{+}\right) ; \quad 30.90 \quad$ (s, $\left.\mathrm{CH}-\underline{\mathrm{C}}_{2}-\mathrm{CH}_{2}\right) ; 26.20$ (d/s, $\left.\mathrm{CH}_{3} \mathrm{CH}_{2} \underline{\mathrm{CH}_{2}} \mathrm{CH}_{2}\right) ; 21.02$ (s, $\left.\mathrm{C}_{\text {aromatic }}-\underline{\mathrm{CH}}_{3}\right) ; 21.02 \quad\left(\mathrm{~s}, \quad \mathrm{CH}_{3} \underline{\mathrm{CH}}_{2} \mathrm{CH}_{2} \mathrm{CH}_{2}\right) ; 18.52 \quad(\mathrm{~s}$, $\left.\mathrm{C}_{\text {aromatic }}-\underline{\mathrm{C}}_{3}\right) ; 13.53\left(\mathrm{~s}, \underline{\mathrm{CH}_{3}} \mathrm{CH}_{2} \mathrm{CH}_{2} \mathrm{CH}_{2}\right) .{ }^{1} \mathrm{H} \mathrm{NMR}\left(\mathrm{CDCl}_{3}\right)$ $\delta$, ppm: $9.75(\mathrm{~d}, \mathrm{~N}-\underline{\mathrm{H}}) ; 6.84\left(\mathrm{~d}, \mathrm{C}_{\text {aromatic }}-\mathrm{CH}_{3}\right) ; 3.95(\mathrm{t}$, C$-\mathrm{N}^{+}$); 3.71 (duplet of triplets, $\left.\underline{\mathrm{CH}}_{2}-\mathrm{N}^{+}\right) ; 3.29\left(\mathrm{~d}, \mathrm{CH}_{3}-\mathrm{N}^{+}\right.$); $2.76 \quad\left(\mathrm{CH}_{2}-\underline{\mathrm{C}}_{2}-\mathrm{N}^{+}\right) ; \quad 2.39 \quad\left(\mathrm{CHCH}_{2} \mathrm{CH}_{2}\right) ; 2.23 \quad(\mathrm{~s}$, $\left.\mathrm{C}_{\text {aromatic }}-\underline{\mathrm{C}}_{3}\right) ; 2.23$ (s, $\left.\mathrm{C}_{\text {aromatic }}-\underline{\mathrm{C}}_{3}\right) ; 2.15$ (s, $\left.\mathrm{C}_{\text {aromatic }}-\underline{\mathrm{C}}_{3}\right)$; $1.83\left(\mathrm{t}, \quad \mathrm{CH}_{2} \mathrm{CH}_{2} \mathrm{CH}_{2}\right) ; 1.7$ (s, $\left.\mathrm{CH}_{2}-\mathrm{CH}_{2}-\mathrm{CH}_{2}-\mathrm{N}^{+}\right) ; 1.37$ $\left(\mathrm{CH}_{2}-\mathrm{CH}_{2}-\mathrm{CH}_{2}-\mathrm{N}^{+}\right) ; \quad 0.96 \quad\left(\mathrm{CH}_{3}-\mathrm{CH}_{2}-\mathrm{CH}_{2}-\mathrm{CH}_{2}-\mathrm{N}^{+}\right)$. Calculated for $\mathrm{C}_{20} \mathrm{H}_{33} \mathrm{~N}_{2} \mathrm{OI}, \%$ : C, 54.05; H, 7.48; N, 6.3; I, 28.56; O, 3.6. Found \%: C, 54.34; H, 7.70.

\section{CONCLUSION}

New ionic compounds based on N-ethoxyethylpiperidine, trimecaine and piromecaine with potential biological activity 
have been synthesized. Optimal conditions for the reactions were found. The prediction of potential biological activity was carried out using PASS online service. Through this service not only potential biological and pharmacological activity, but also potential toxic effects and compared change of activities between similar compounds with different carbon radicals was determined. The results will be used in the field of synthesis of new ionic compounds and new drug candidates.

\section{REFERENCES}

[1] G. I. Samarina, "Chemical and stereochemical structure of piperidine and decahydroquinoline derivatives and their pharmacological activity," PhD thesis, Almaty State University, Almaty, Kazakhstan, 1972.

[2] J. Stoimenovski, D. R. MacFarlane, K. Bica and R. D. Rogers, "Crystalline vs. Ionic Liquid Salt Forms of Active Pharmaceutical Ingredients: A Position Paper," Pharmaceutical Research, vol. 16, pp. 521-526, 2010.

[3] K. D. Praliev, A. D. Nagimova, V. K. Yu, S. N. Shin, and N. de Kimpe, "Novel cyan-ethyl ethers of 1-(2-ethoxyethyl)-4-hydroxypiperidines and their carboxylic acids," Izvestiya MES of RK, ser. khim, pp. 82-88, 2001.

[4] V. K. Yu, A. D. Nagimova, K. D. Praliev, S. N. Shin, and N. D. Kimpe, "Synthesis, antibacterial and analgesic activity of 1-(2-ethoxyethyl)-4-hydroxy(acyloxy)piperidine carboxylic acids," Khim.-farm. Zh., vol. 36, pp. 59-61, 2002.

[5] V. K. Yu, A. D. Nagimova, K. D. Praliev, and I. B. Sagatbekova, "Piperidine-carboxylic acids of piperidine row," Khim. Zh. Kaz., pp. 90-103, 2009.

[6] Y. F. Krylov, Registry of Russian Drugs: Encyclopedia of Drugs, 8th ed., Revised and Expanded, RLS, Moscow, 2001.

[7] V. Yu, A. Zazybin, K. Praliyev, A. Ten, A. Basharimova, S. Bayazit, and M. Naukanova, "Kazcaine as a lead compound for novel pharmacologically active substances," presented at the 13th International Kyoto Conference on New Aspects of Organic Chemistry (IKCOC-13), Kyoto, Japan, November 9-13, 2015.

[8] E. E. Stoliarov, I. N. Karpenko, and T. L. Malkova, "Detection of certain local anesthetics in biological fluids by chemo-toxicological analysis, Sud Med Ekspert, vol, 52, no. 3, pp. 24-70, May-Jun. 2009.

[9] V. P. Balashov, D. S. Blinov,V. N. Kazachenko, M. E. Astashev, O. G. Agenosova, "Membrane mechanisms of antiarrhythmic effect of quaternidine,” Bull Exp Biol Med., vol. 139, no. 6, pp. 688-91, Jun. 2005.

[10] O. V. Tsyhykalo, "Topographical ahatomy and operative surgery: textbook for english-speaking foreign students," Nova Kniha Pulishers, p. 528, 2011.

[11] E. L. Gortsakalian, V. N. Nesvetov, and V. K. Smirnov, "Effect of piromecaine on central hemodynamics in myocardial infarction," Sov Med., vol. 7, pp. 76-80, 1987.

[12] PASS online service. [Online]. Available: http://pharmaexpert.ru/passonline/index.php

[13] A. Lagunin, A. Zakharov, D. Filimonov, and V. Poroikov, "QSAR Modelling of Rat Acute Toxicity on the Basis of PASS Prediction," Molecular Informatics, vol. 30, no. 2-3, pp. 241-250, 2011.

[14] A. Lagunin, D. A. Filimonov, and V. V. Poroikov, "Multi-targeted natural products evaluation based on biological activity prediction with PASS," Cur. Phar. Des., vol. 16, no. 15, pp. 1703-1717, 2010.

[15] I. Heilbron, E. R. H. Jones, M. Julia, and B. C. L. Weedon, "Studies in the polyene series. Part XXIX. Ethoxyacetylenic carbinols and their conversion into $\alpha, \beta$-unsaturated aldehydes and acids," Journal of the Chemical Society (Resumed), p. 1823, 1949.

[16] É. I. Gendenshtein, Y. V. Kostin, V. P. Balashov, and V. É. Oleinikov, "Combined action of antiarrhythmic agents," Bulletin of Experimental Biology and Medicine, vol. 111, pp. 820-822, 1991.

[17] S. D. Yuzhakov, Drugs, p. 704, 2014.

[18] M. Shapero and P. J. Southgate, "The pharmacology of ambenoxan (2-(3',6'-dioxaheptyl)-aminomethyl-1:4-benzodioxane), a centrally acting muscle relaxant," British Journal of Pharmacology, vol. 38, pp. 263-270, 1970 .

[19] V. Poroikov and D. Filimonov, "Computer-aided prediction of biological activity spectra. Application for finding and optimization of new leads," Rational Approaches to Drug Design, Barcelona, pp. 403-407, 2001.

[20] V.Poroikov, D. Akimov, E. Shabelnikova, and D. Filimonov, “Top 200 medicines: Can new actions be discovered through computer-aided prediction?" SAR and QSAR in Environmental Research, vol. 12, no. 4, pp. 327-344, 2001.

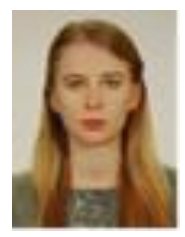

D. S. Zolotareva was born in Almaty city, Kazakhstan in 1993. She received the bachelor's degree in chemical engineering in Kazakh-British Technical University in 2015. Currently, she's getting the master's degree in chemical engineering in Kazakh-British Technical University. Her major field is in ionic liquids with potential biological activity. 